\title{
TYPES OF MOOD \\ USED BY THE LECTURER IN TEACHING READING: A SYSTEMIC FUNCTIONAL LINGUISTIC ANALYSIS
}

\author{
Sri Mulatsih, Sunardi \\ Universitas Dian Nuswantoro
}

\begin{abstract}
Teaching Reading is a way to develop students' awareness and to facilitate students to learn the reading skill in order to develop students engaged with the text they read in a meaningful way. In teaching reading, the lecturer used several types of mood to make the students understand the materials. This study is aimed at describing the types of mood used by the lecturer in teaching two reading classes in a private university in Semarang, Central Java, Indonesia. This study used qualitative research design since it describes certain phenomenon that is types of mood used by the lecturer in teaching Reading. The setting of this research is in English Department, Universitas Dian Nuswantoro Semarang, Central Java, Indonesia. The data are in the forms of utterances used by the lecturer in teaching Reading. Data collection was done by observing and taking notes on the teaching and learning process of Reading, video recording the teaching and learning process of Reading, viewing the data to show the completeness of the data, and transcribing the recorded data into the written forms. They were analyzed using qualitative data analysis offered by Creswell (2009), those are organizing and preparing data, coding and segmenting the written data into clauses, identifying the type of mood, classifying the type of mood, and interpreting the data. The result showed that the type of mood mostly used by the lecturer in teaching Reading is declarative because the lecturer gives much information to the students to make the students understand the materials. Other types of mood used are interrogative and imperative ones.
\end{abstract}

Key words: interpersonal meaning, mood types, systemic functional linguistics, teaching reading

\section{INRODUCTION}

Reading is a process of understanding texts in order to construct or derive meaning. When someone reads, he uses his eyes to receive written symbols (letters, punctuation marks and spaces) and he uses our brain to convert them into words, sentences and paragraphs that communicate something to him. Reading can be silent (in someone's head) or aloud (so that other people can hear). Reading is a receptive skill - through reading we can receive some information.

Reading is also a conscious process. When someone reads a text he should have sufficient prior knowledge about the text he reads. Without it, it will be very difficult for us to understand the content of the text. Reading skill is the cognitive process that a reader uses in making sense of a text. For fluent readers, most of the reading skills are employed unconsciously and automatically. When confronted with a challenging text, fluent readers apply these skills consciously and strategically in order to comprehend. That is why to comprehend the content of certain reading, it needs be taught in class. There should be a teaching of Reading. (Richards \&Renandya, 2002) 
Teaching reading is a way to develop students' awareness and to facilitate students to learn the reading skill in order to develop students engaged with the text they read in a meaningful way. Teaching Reading is a complex process, it doesn't only give the information from the teacher to the students but it is also one of ways to make the students' understanding in teaching - learning process. (Richards \& Renandya, 2002)

In teaching reading to the students, the lecturer usually uses several types of mood. They refer to the organization of the set of functional constituents including constituent of subject. The mood system at the clause encodes the relationship between the participants in an interaction as well as the speakers or writer's attitude and judgement.(Eggin, 1994). Types of mood in the classroom refer to the types of exchange done by the lecturer whether giving, asking or demanding information.

There are several previous studies that discuss about the types of mood. The first one was conducted by Amaliaet.al. (2018). It discussed about the types of mood and modality used in SusiloBambangYudhoyono's (SBY's) speech. The result showed that the dominant mood types used is declarative. In his speech, SBY gave several information to the audience. The second previous study was conducted by Putri and Muhdi (2018). It analyzed the type of mood used in financial services tagline. The result showed that the type of mood dominantly used in the tagline is also declarative because the function of these taglines is giving information about certain product. The difference between this study and the previous ones lies on the setting and the data. The setting of this study is in a classroom discourse that is in reading classes, while the data are in the form of the lecturer's utterances used in the teaching and learning process. That is why the aim of this study is to describe the types of mood used by the lecturer in teaching Reading. This study used systemic functional linguistic approach in analyzing the data.

\section{Systemic Functional Linguistics}

Systemic Functional Linguistics is one of linguistic branches in which language is a resource for making and expressing meanings, both what we would think of as linguistic meanings and higher - level meanings relating to various aspects of social systems (culture) (Matthiessen, 1995:1). As Butt et.al.(2000: 7) stated "Systemic Functional Linguistics is a way of describing lexical and grammatical choices from the systems of wordings so that we are always aware how language is being used to realize meanings. There are three types of meanings that are realized, they are ideational meanings, interpersonal meanings, and textual meanings. Ideational meaning is meaning about phenomena - about things (living and non-living, abstract and concrete), about goings on (what the things are and do) and the circumstances surrounding these happenings and doings. Interpersonal meaning: meaning about roles and relationship. Textual meaning is meaning about the message. Since this study focuses on types of mood as part of interpersonal meanings, these meanings are explained further. 


\section{Interpersonal Meaning}

Interpersonal meaning of a clause is also called as meaning as exchange. This meaning expresses a speaker's attitudes and judgments. In this case the clause is also as an interactive event involving speaker, writer, and audience. Concerning this, Halliday (1994:68) points out that a clause has a meaning as an exchange. It is the element the speaker makes responsible for the validity of what he is saying. It implies that in the act of speaking the speaker adopts for himself a particular speech role, and in so doing assigns to the listener a complementary role that wishes him to adopt in his turn. In asking a question, for example, a speaker is taking on the role of supplier of the information demanded.

Interpersonal meanings cover two main areas; one concerns the type of interaction taking place and the kind of commodity being exchanged, and the other concerns the way speaker take a position in their message, Butt et.al.(2001). The interaction taking place is whether the language is used to demand or to give the commodity, that is, the usage of language to exchange information or to exchange goods and services. In other words, language is used to give or demand information, and to give or demand goods and services. These interpersonal meanings from semantic level of language are realized in the wordings of the lexicogrammatical level. The interpersonal meanings focus on the order of the grammatical features: Subject and Finite. Finites are showing tense or speaker's attitude. Subject and Finite combine to make the Mood of the clause.

\section{Types of Mood}

Eggins (1994:152) states that the mood structure of the clauses refers to the organization of the set of functional constituents including constituent of subject. The mood system at the clause encodes the relationship between the participants in an interaction as well as the speakers or writeres attitude and judgement.. Types of mood based on Butt et,al (2001) are declarative, interrogative (Polar or Wh), imperative, and exclamative.

Declarative clauses can be identified as clauses in which the structural element of Subject occurs before the Finite element of the clause.

Polar interrogatives, also known as yes-no interrogatives, can be identified as clauses where the Finite element occurs before the Subject. Wh-interrogative clauses are recognized by the presence of a wh-question word, e.g. who, what, which, when, why, how, etc. The purpose of the wh-word is to probe for a missing element of clause structure. The wh-word is always conflated with another element of clause structure. It may be conflated with either the Subject, the Complement or Circumstantial Adjunct, and is shown as a constituent of the Mood or Residue according to the status of the element with which it is conflated. The order of constituents in a wh-interrogative depends on which element of clause structure is being probed. When the element probed for is the Subject, then the wh-word occurs before the Finite. However, when the wh-word probes any other element of clause structure (e.g. Complement or Circumstantial Adjunct), then a separate Finite element must be used, with the Finite being placed before the Subject.(Gerot and Wignell, 1994) 
Imperative clauses normally realize moves of demanding goods-\&services. They typically do not contain the element of Subject or Finite but consist of only a Predicator, plus any of the non-core participants of Complement and Adjunct. The Subject is typically implicit if it is the imperative default Subject, you. If they are positive, there is no Finite; if they are negative, there is one; however, it may be absent.

Exclamative clauses, which are typically used to encode a judgement or evaluation of events, are a blend of interrogative and declarative patterns. Like the wh-interrogatives, they require the presence of a wh-word, conflated with either a Complement or an Adjunct. Structurally, they have the patterns of declarative, with the Subject preceding the Finite.

\section{Teaching Reading}

In the classroom, teaching reading is a way transferring knowledge from teacher to students by using a certain technique of strategy and a certain material in order to master reading itself. Teaching is a complex process it doesn't only give the information from the teacher to the students. Reading is one of ways to make the students understanding in teaching - learning process. According to Harmer (2001: 23) teaching is not an easy job, but it is a necessary one and can be very rewarding when we see our student's progress and know that we have helped to make it happen. It is true that some students can be difficult and stressful at times, but it is also worth remembering that at its best teaching can also be extremely enjoyable. Based on explanation, the writer concludes that teaching activities and manages the environment in a good condition to make and give the opportunity for the students in learning process to get the purpose.

Based on Harmer (1998:68) reading is useful for other purposes too: any exposure to English provided students understand it more or less is a good thing for language students. 13 In teaching reading, the teacher's responsibilities in helping learners achieve these goals is to motivate reading by selecting or creating appropriate texts, to design useful reading tasks, to set up effective classroom procedure, to encourage critical reading, and to create supportive environment for practicing reading. In the classroom, teacher has to decide what the purpose in reading will be done. It is reading for pleasure or getting understands the passage. If the purpose of reading that will be done is for pleasure, the topic of reading text can be free. And if the purpose of reading text that will be done is for getting understands the passage, so the topic of reading text should be prepared before teacher teach in reading class.

According to Anderson (2005), there are eight principles of teaching reading: First, exploiting the reader's background knowledge, second, building a strong vocabulary base, third, teaching for comprehension, fourth, working on increasing reading rate, fifth, teaching reading strategies, sixth, encouraging readers to transform strategies into skills, seventh, building assessment and evaluation into teaching and eighth, striving for continuous improvement as a reading teacher. 


\section{METHOD}

\section{Research Design}

This study used qualitative design. Qualitative design is defined as a method for studying and understanding the problems emerge in human or social context. The process is based on the question arise, it is analyzed and interpreted based on the data collected in the participant' milieu. The data is often analyzed from specific to a more general theme (Creswell, 2009). This study is qualitative one because it describes certain phenomenon that is the types of mood used by the lecturer in Teaching Reading.

\section{Setting and Participant of the Study}

This study is aimed at describing the types of mood used by the lecturer in teaching Reading. The setting of this research is in 2 Reading classes in English Department, Universitas Dian Nuswantoro Semarang, Central Java, Indonesia. This teaching used genre-based approach. The participant is a lecturer who teaches Reading in that university. The data in this study are in the form of utterances (spoken languages) produced by the lecturer in two Reading Classes. An utterance is the smallest unit of speech. It is a continuous piece of speech beginning and ending with a clear pause.

\section{Technique of Data Collection}

The steps to collect the data in this study were observing and taking notes on the teaching and learning process of Reading, video recording the teaching and learning process of Reading, viewing the data to show the completeness of the data, and transcribing the recorded data into the written forms.

\section{Technique of Data Analysis}

The data collected then were analyzed in various ways in order to answer the research question. The qualitative data which are in the form of teachers' utterances were analyzed using qualitative data analysis offered by Creswell (2009). Those steps were organizing and preparing data, coding and segmenting the written data into clauses, identifying the type of mood, classifying the type of mood, and interpreting the data.

\section{RESULTS AND DISCUSSION}

This part discusses the types of mood used by the lecturer in teaching Reading. As stated in the previous part, mood is the order of the grammatical features: Subject and Finite. Subject and Finite combine to make the Mood of the clause. Whereas the other elements, Predicator, Adjunct, and Complement, are the Residue of the clause. 
Table 1. Types of Mood Used by the Lecturer in Teaching Reading

\begin{tabular}{clcccc}
\hline No & Types of Mood & \multicolumn{2}{c}{ Reading Classes } & $\sum$ & $\%$ \\
& & Class 1 & Class 2 & & \\
\hline 1 & Declarative & 234 & 475 & 709 & 67 \\
2 & Interrogative & 132 & 153 & 285 & 27 \\
3 & Imperative & 26 & 38 & 64 & 6 \\
\hline & & 392 & 654 & 1,058 & 100 \\
\hline
\end{tabular}

Table 1 show that there are three types of mood used by the lecturer in teaching Reading. They are declarative (709), interrogative (285), and imperative (64). The dominant mood type used in teaching Reading is declarative. This condition is caused by the fact that in teaching Reading the lecturer gives some explanation or information related to the materials being discussed in the classroom. The second mood type used is interrogative. This mood is used to ask students several questions to know the students' understanding about the materials. And the last mood type used is imperative. This type of mood is used by the lecturer to command students to do something such as reading the text or writing the answers on the white board. The examples of mood types used by the lecturer in teaching Reading can be seen on the following examples.

\section{Declarative}

The excerpts below are some examples of declarative clause used by the lecturer in teaching Reading.

\section{Excerpt 1}

The social function of procedure text is how to accomplish something,

\begin{tabular}{|l|l|l|l|}
\hline $\begin{array}{l}\text { The social function of } \\
\text { procedure text }\end{array}$ & \multicolumn{2}{|c|}{ is } & $\begin{array}{l}\text { how to accomplish } \\
\text { something }\end{array}$ \\
\hline Subject & finite & predicator & complement \\
\hline \multicolumn{2}{|c|}{ Mood } & \multicolumn{2}{|c|}{ Residue } \\
\hline
\end{tabular}

Excerpt 2

Procedure texts are found everywhere.

\begin{tabular}{|l|l|l|l|}
\hline Procedure text & \multicolumn{2}{|c|}{ are found } & everywhere \\
\hline Subject & Finite & Predicator & Adjunct \\
\hline \multicolumn{2}{|c|}{ Mood } & \multicolumn{2}{c|}{ Residue } \\
\hline
\end{tabular}

Excerpt 3

Now I have corrected your assignment

\begin{tabular}{|l|l|l|l|l|}
\hline Now & $I$ & \multicolumn{2}{|c|}{ have corrected } & your assignemnt \\
\hline Adjunct & Subject & finite & predicator & complement \\
\hline \multicolumn{3}{|l|}{ Mood } & \multicolumn{2}{|c|}{ Residue } \\
\hline
\end{tabular}


The examples in excerpt 1-3are called declarative clauses because the subject occurs before the finite element of the clause. The function of this clauses is to give information about something. In excerpt 1 , the lecturer gives the information about the function of procedure text. That is how to accomplish something. In excerpt 2, the lecturer gives information that the procedure text can be found everywhere. It can be in the instruction on how to make some food, or can be the instruction on how to operate certain machine. In excerpt 3 , the lecturer gives the information to the students that she had corrected their assignment.

\section{Interrogative}

The examples of interrogative clauses can be found in the following examples.

Excerpt 4

Have you all got the materials?

\begin{tabular}{|l|l|l|l|}
\hline Have & you all & got & the materials \\
\hline Finite & subject & predicator & complement \\
\hline \multicolumn{2}{|c|}{ Mood } & \multicolumn{2}{c|}{ residue } \\
\hline
\end{tabular}

\section{Excerpt 5}

What is the schematic structure of procedure text?

\begin{tabular}{|l|l|l|l|}
\hline What & \multicolumn{2}{|c|}{ is } & $\begin{array}{l}\text { the schematic structure of } \\
\text { procedure text? }\end{array}$ \\
\hline Subject & Finite & predicator & complement \\
\hline \multicolumn{2}{|c|}{ Mood } & \multicolumn{2}{c|}{ Residue } \\
\hline
\end{tabular}

\section{Excerpt 6}

How do you download video from YouTube right now?

\begin{tabular}{|c|l|l|l|l|}
\hline How & do & you & download & $\begin{array}{l}\text { video from } \\
\text { YouTube right } \\
\text { now? }\end{array}$ \\
\hline $\begin{array}{l}\text { Wh adjunct: } \\
\text { circ. }\end{array}$ & Finite & subject & predicator & complement \\
\hline Residue... & \multicolumn{2}{|c|}{ Mood } & \multicolumn{2}{|c|}{..residue } \\
\hline
\end{tabular}

The examples in excerpt. 4-6 are classified into interrogative because this clauses function to demand some information. In excerpt 4 the lecturer asks the students whether they have got the materials she had uploaded. In excerpt 5, the lecturer asks the students about the schematic structure of procedure text. In excerpt 6 , the lecturer asks the students how they downloaded video from You Tube. 


\section{Imperative}

\section{Excerpt 7}

Look at the language of the instruction!

\begin{tabular}{|l|l|}
\hline Look at & the language of the instruction! \\
\hline Predicator & complement \\
\hline Mood & Residue \\
\hline
\end{tabular}

Excerpt 8

Raise your hand!

\begin{tabular}{|l|l|}
\hline Raise & your hand! \\
\hline Predicator & complement \\
\hline Mood & Residue \\
\hline
\end{tabular}

Excerpt 9

Read it as you read a story not flat!

\begin{tabular}{|l|l|}
\hline Read & it as you read a story not flat! \\
\hline Predicator & complement \\
\hline Mood & Residue \\
\hline
\end{tabular}

The clauses is excerpt 7-9 are all classified as imperative sincethey typically do not contain the element of Subject or Finite but consist of only a Predicator, plus any of the non-core participants of Complement and Adjunct. The Subject is typically implicit if it is the imperative default Subject, you. The function of these clauses is to make others do something. In excerpt 7 the lecturer asks the students to look at the language of instruction in procedure text they bring, Inexcerpt 8 the lecturer asks the students to raise their hands if they can answer the question given by the lecture. In excerpt 9 the lecturer ask the student to read a certain text with the intonation as they read a story.

\section{CONCLUSION AND IMPLICATION}

Based on the explanation on the previous part, it can be concluded that there are three types of mood used by the lecturer in teaching Reading. They are declarative, interrogative, and imperative. Declarative mood is dominantly used in the classroom since in teaching Reading the lecturer gives some information and also explanation related to the materials being discussed in the classroom to make the students understand them. Interrogative clauses are also used in the classroom to ask the students some questions to know their understanding about the materials. Imperative clauses are used to command the students to do something such as reading the text or demonstrating something.

The pedagogical implication that can be taken from this study is that the lecturer should consider the use of mood types in the process of teaching and learning since this will determine the success of the teaching. 


\section{REFERENCES}

Amalia, Mustika, et.al. (2018). An Analysis of Domain Mood and Modaality of Interpersonal Meaning in Susilo Bambang Yudhoyono's (SBY's) Speech.English Language Teaching Education Journal (ELTEJ).Vol. 1.No.1. August 2018-pp.22-28.

Anderson, Neil J. (2005). Fluency in L2 Reading and Speaking.TESOL 2005 colloquium.

Butt, David, et.al.. (2001). Using Functional Grammar: An Explorer's Guide Second Edition. Sydney: National Centre for English Language Teaching and Research Macquarie University.

Creswell.J.W. (2009). Research Design: Qualitative, Quantitative, and Mix Method Approaches (3 ${ }^{\text {rd }}$ Edition). United States of America: Sage Publications, Inc.

Derewianka, Beverly. (1990). Exploring How Texts Work. Australia: Primary English Teaching Association

Eggin, Suzanne. (1994). An Introduction to Systemic Functional Linguistics. London: Printer Publishers.

Gerot, Linda and Wignell, Peter.(1994). Making Sense of Functional Grammar. New South Wales: GerdStabler.

Halliday, M.A.K. (1994). An Introduction to Functional Grammar. Second Edition.London: Edward Arnold.

Halliday, M.A.K. and C.M.I.M. Matthiessen. (1999). Construing Experience Through Meaning: A Language - Based Approach to Cognition. London: Continuum.

Harmer, Jeremy. (1998).How to Teach Writing. Essex: Pearson Education.

Harmer, Jeremy, (2001).The Practice of English Language Teaching.4rd Edition.Longman.

Matthiessen, C.M.I.M. (1995). Lexicogrammatical Cartography: English Systems. Tokyo: International Language Sciences Publishers.

Putri, G. Jayanti.\&Muhdi, Setiono. (2018). Mood Analysis of Financial Services taglines : A SFL approach.UI.Proceeding of Social Science and Humanities.

Richards, J.C., \&Renandya, W.A. (2002).Methodology in language teaching: Ananthology of current practice. Cambridge:Cambridge University Press. 